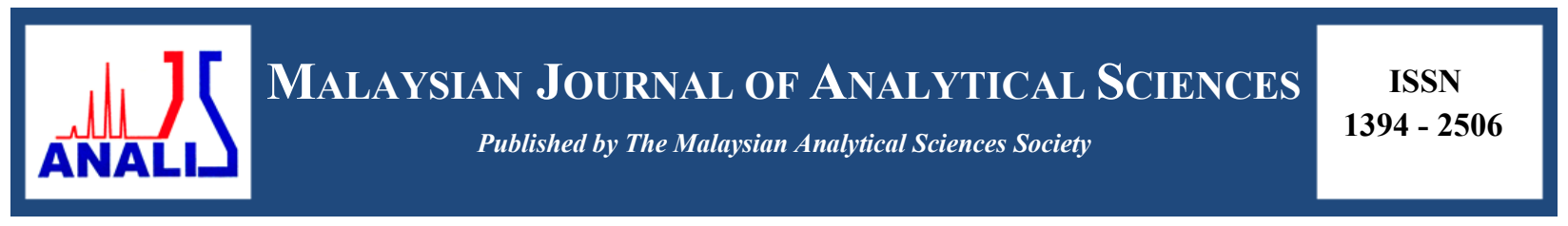

\title{
PHYTOCHEMICAL SCREENING, TOTAL FLAVONOID AND PHENOLIC CONTENT ASSAYS OF VARIOUS SOLVENT EXTRACTS OF TEPAL OF Musa paradisiaca
}

\author{
(Penyaringan Fitokimia, Jumlah Asai Kandungan Flavonoid dan Fenolik Pelbagai Ekstrak \\ Pelarut Tepal Musa paradisiaca) \\ U.S. Mahadeva Rao ${ }^{1 *}$, Muhammad Abdurrazak ${ }^{1}$, Khamsah Suryati Mohd ${ }^{2}$ \\ ${ }^{I}$ Faculty of Medicine, \\ Universiti Sultan Zainal Abidin, Kota Campus, 20400 Kuala Terenganu, Terenganu, Malaysia \\ ${ }^{2}$ Faculty of Bioresources and Food Industry, \\ Universiti Sultan Zainal Abidin, Tembila Campus, 22200 Besut, Terenganu, Malaysia \\ *Corresponding author: raousm@gmail.com
}

Received: 14 April 2015; Accepted: 3 August 2016

\begin{abstract}
The objective of this research is to conduct the preliminary phytochemical screening, total flavonoid and phenolic contents assays of various solvent extracts of tepal of Musa paradisiaca. Phytochemical screening was carried out according to the method of Trease and Evans, total flavonoid content was measured by the aluminium chloride colorimetric assay and total phenolic content was estimated spectrophotometrically by Folin-Ciocalteau method. - Preliminary phytochemical screening reveals the presence of phenolics, flavonoids, alkaloids, tannins, terpenoids in all the three different extracts (methanolic, ethanolic and aqueous). Tepal methanolic extract has the richest content of both phenolics and flavonoids i.e. (4.27 mg GAE/g and $0.25 \mathrm{mg} \mathrm{QE} / \mathrm{g}$ ) respectively, and aqueous extract was the least i.e. (1.32 $\mathrm{mg} \mathrm{GAE} / \mathrm{g}$ and $0.164 \mathrm{mg} \mathrm{QE} / \mathrm{g})$. All the extracts were not significantly different with one another $(p>0.05)$. It can be hypothesised that the high contents of phenolic compounds of tepals of Musa paradisiaca indicated that these compounds contribute to the antioxidant activity and can be regarded as promising plant species for natural sources of radical scavenging activity with potential value for treatment of many life threatening diseases.
\end{abstract}

Keywords: phytochemical, flavonoid, phenolics, Musa paradisiaca

\section{Abstrak}

Objektif kajian ini adalah untuk menjalankan pemeriksaan awal ke atas ketulenan fitokimia, jumlah kandungan fenolik flavonoid dan pelbagai ekstrak pelarut tepal Musa paradisiaca. Penyaringan fitokimia telah dilaksanakan mengikut kaedah Trease dan Evans, dimana jumlah kandungan flavonoid diukur oleh ujian kalorimetrik aluminium klorida dan jumlah kandungan fenolik dianggarkan secara spektrofotometer dengan kaedah Folin-Ciocalteau. Penyaringan awal fitokimia menunjukkan kehadiran fenolik, flavonoid, alkaloid, tannin dan terpenoid dalam ketiga-tiga ekstrak yang berbeza (metanol, etanol dan akueus). Ekstrak metanol Tepal mempunyai kandungan yang paling tinggi di antara kedua-dua fenolik dan flavonoid iaitu sebanyak $4.27 \mathrm{mg}$ $\mathrm{GAE} / \mathrm{g}$ dan $0.25 \mathrm{mg} \mathrm{QE} / \mathrm{g}$, manakala ekstrak akueus adalah mempunyai kandungan terendah iaitu sebanyak $1.32 \mathrm{mg}$ GAE/g dan $0,164 \mathrm{mg} \mathrm{QE} / \mathrm{g}$. Semua ekstrak tidak berbeza secara ketara antara satu sama lain $(\mathrm{p}>0.05)$. Oleh itu, hipotesis yang boleh dibuat adalah kandungan yang tinggi sebatian fenolik daripada tepal Musa paradisiaca menyumbang kepada aktiviti antioksidan dan boleh dianggap sebagai spesies tumbuhan yang berpotensi untuk merawat pelbagai penyakit yang mengancam nyawa.

Kata kunci: fitokimia, flavonoid, fenolik, Musa paradisiaca 


\section{Introduction}

Consumption of medicinal herbs protects and heals a number of ailments and they have been the principal treatment therapy in prehistoric times until the discovery of synthetic drugs in the nineteenth century [1]. This exploration of biologically active natural products has played an important role in finding new chemical entities (NCEs), for example, approximately $28 \%$ of NCEs between 1981 and 2002 were natural products or natural product-derived [2]. Health benefits has been derived from bioactive compounds that are commonly found in edible plant parts such as fruits, vegetables, flowers, leaves and have been shown to confer protection against various ailments [3]. Interestingly, many of them are known to contain large amounts of phenolic antioxidants [4]. Phytchemicals have become an intense focus of research interest because of their perceived beneficial effects for health, including anticarcinogenic, antiatherogenic, antiulcer, anti-thrombotic, anti-inflammatory, immunemodulating, antimicrobial, varodialatory, and analgesic effects. Therefore, the search for exploitation of natural antioxidants, especially of plant origin, has greatly increased in recent years [1]. For example, chard extract (Beta vulgaris L. var. cicla) has been used as a hypoglycaemic agent by diabetic mellitus (DM) patients in Turkey [5] and it has been documented that the number of similarly various phytoconstituent such as epicatechin, rutin, quercetin, nymphayol and flavonoid extracts from Pterocarpus marsupium have shown to possess $\beta$-cells regeneration capacity [6].

Flavonoids represent the most common and widely distributed group of plant phenolics [7] and are abundant in foods; quercetin and rutin are the flavonoids most abundantly consumed [8]. Musa paradisiaca is one of the wellknown plants of the Musaeae family that have been used in traditional medicine since hundred years to alleviate various diseases and health problems. Active constituent presence in the plants materials might be responsible to the beneficial of human health. The most important of these bioactive compounds of plants are alkaloids, flavonoids, tannins and phenolic compounds [9]. Ethnomedicinal survey around the world revealed that the flowers of Musa spp. have been used to treat many illnesses. Its flowers have been traditionally used to alleviate menorrhagia, dysentery, diabetes mellitus [10], heart pain, diarrhea, stomach cramps and infantile malnutrition [11]. It was reported that the extracts of the flowers possess medicinal properties for illness such as diabetes mellitus, anaemia [12] and malaria [13]. Phenolics are the largest group of phytochemicals that account for most of the antioxidant activity in plants or plant products [14].

More than 4000 polyphenols (flavonoids, monophenols and poly phenols) are found in vascular plants. Phenolic compounds such as quercetin, rutin, narigin, catechin, caffeic acid, gallic acid and chlorogenic acid are very important plant constituents [15]. Flavonoids are the largest group of naturally occurring phenolic compounds, which occurs in different plant parts in Free State and as glycosides [16]. They are found to have many biological activities including antimicrobial, mitochondrial adhesion inhibition, antiulcer, antiarthritic, antiangiogenic, anticancer, protein kinase inhibition etc. The flavones and flavonols are the most widely distributed of all the phenolics [17]. Flavonoids are particularly beneficial, acting as antioxidants and giving protection against cardiovascular disease, certain forms of cancer and age related degeneration of cell components. Their polyphenolic nature enables them to scavenge injurious free radicals such as super oxide and hydroxyl radicals [18]. A variety of dietary plant flavonoids inhibits tumor development in experimental animal models [19]. The bi-flavonoids have the pharmacological effects like their ability to inhibit the release of histamines, the adhesion of blood platelets and the action of lens aldose reductase, to block the inflammatory effects of hepatotoxins, and to act as a heart stimulant [20]. Therefore, the objective of this paper is to carry out the phytochemical screening, total contents of both phenolics and flavonoids of various solvent extracts of Musa paradisiaca.

\section{Preparation of plant extract}

\section{Materials and Methods}

The tepals were selectively removed from the bracts, oven dried for one week. It was then crush grinded to fine powder using an electrical grinder. This was then divided into three portion and each portion was soaked in methanol, ethanol and distilled water for 3 days respectively. Each sample was later filtered using Whatmann's No. 1 filter paper. The filtrates were then concentrated at $42{ }^{\circ} \mathrm{C}$ to yield a dark brown semi solid using a rotary evaporator (N-1100, Shanghai, Eyela. Co. Ltd, Tokyo, China). This was repeated three times. For each extract, the yield was expressed in percentage by dividing the quantity of dry mass obtained after extraction by the dry weight of the powder used before soaking. Dried extracts were weighed and dissolved in 10\% dimethylsulphoxide (DMSO) 
to yield a stock solution from which lower concentrations were prepared. The filtrate was then concentrated using an electric incubator. The extract appears as semi-solid greenish brown paste. A stock solution to be used was then prepared by dissolving $100 \mathrm{~g}$ of the extract in $50 \mathrm{ml}$ of distilled water.

\section{Preliminary phytochemical screening}

The phytochemical screening of the extracts was conducted using standard procedures described by Trease and Evans [21]. The following qualitative tests were carried out:

\section{Test for saponins}

One $\mathrm{mL}$ of the tepal extract was diluted with distilled water to $20 \mathrm{~mL}$ and shaken in a graduated cylinder for 15 minutes. The formation of one centimeter layer of foam indicates the presence of saponins.

\section{Test for phenols}

A small amount of the ethanolic extract was taken with $1 \mathrm{~mL}$ of water in a test tube and 1 to 2 drops of Iron III chloride $\left(\mathrm{FeCl}_{3}\right)$ was added. A blue, green, red or purple color is a positive test.

\section{Test for glycosides}

A small amount of alcoholic extract was taken in $1 \mathrm{~mL}$ of water in a test tube and a few drops of aqueous $\mathrm{NaOH}$ were added. A yellow coloration indicates the presence glycosides.

\section{Test for flavonoids}

One to five drops of concentrated hydrochloric acid $(\mathrm{HCl})$ were added to little amount of ethanolic extract of the plant material. Immediate development of a red colour indicates the presence of flavonoids.

\section{Test for alkaloids}

Two $\mathrm{mL}$ of extract was taken in a test tube and then $0.2 \mathrm{~mL}$ dilute $\mathrm{HCl}$ was included, followed by $1 \mathrm{~mL}$ of Meyer's reagent. A yellowish coloration indicates alkaloid's presence.

\section{Test for tannins}

Five $\mathrm{mL}$ of the tepal extract was placed in a test tube and then $2 \mathrm{~mL}$ of $5 \%$ of $\mathrm{FeCl}_{3}$ solution was added. A greenish-black precipitate indicates the presence of tannins.

\section{Test for terpenoids}

In a test tube containing $2 \mathrm{~mL}$ of chloroform, $0.5 \mathrm{~mL}$ of extract was added. This is then followed by the addition of $3 \mathrm{~mL}$ conc. $\mathrm{H}_{2} \mathrm{SO}_{4}$ which forms a layer. Reddish brown coloration of the interface indicates terpenoids.

\section{Total phenolic content assay}

The total phenolic content (TPC) was carried out by using the method of Folin-Ciocalteu. An aliquot (least amount) $(1 \mathrm{~mL})$ of extracts or standard solution of gallic acid $(100,200,300,400$, and $500 \mu \mathrm{g} / \mathrm{mL})$ was added to $25 \mathrm{~mL}$ of volumetric flask, containing $10 \mathrm{ml}$ of decontaminated water. A blank reagent using distilled water was prepared. One $\mathrm{mL}$ of Folin-Ciocalteu phenol reagent was added to the mixture and shaken. After 5 mins $10 \mathrm{~mL}$ of $7.5 \%$ $\mathrm{Na}_{2} \mathrm{CO}_{3}$ solution was added to the mixture. The volume was then made up to the mark. Upon completion of incubation for 30-45 minutes at room temperature, the absorbance against the reagent blank was determined at 760 $\mathrm{nm}$ with an UV-Visible (Shimadzu Japan). TPC was expressed as mg gallic acid equivalents (GAE) [22].

\section{Total flavonoid content assay}

In this method, quercetin was used as the standard to make the calibration curve. $3.2 \mathrm{mg}$ of quercetin was dissolved in $95 \%$ ethanol and then diluted to $5,10,20,40,80,160$, and $320 \mu \mathrm{g} / \mathrm{mL}$. A calibration curve was made by measuring the absorbance of the dilutions at $415 \mathrm{~nm}$ ( $\lambda_{\max }$ of quercetin) with a UV-1800 spectrophotometer Shimadzu Japan. Aluminium chloride $\left(\mathrm{AlCl}_{3}\right), 10 \%$ and potassium acetate, $1 \mathrm{M}$ solution was prepared. An amount $50 \mathrm{mg}$ of each extract was accurately weighed and transferred to $10 \mathrm{~mL}$ volumetric flask and made up the volume with methanol. $50 \mu \mathrm{L}$ of each extract stock solution, $2.15 \mathrm{ml}$ ethanol, $0.1 \mathrm{~mL} \mathrm{AlCl}_{3} 0.1 \mathrm{ml}$ potassium acetate solution and $2.8 \mathrm{~mL}$ distilled water were added and mixed well. Sample blank was prepared in a similar way by 
replacing $\mathrm{AlCl}_{3}$ with distilled water. Sample and sample blank of all extracts were prepared and their corresponding absorbances were measured at $415 \mathrm{~nm}$. All prepared solutions were filtered through whatmann filter paper before measuring. Total flavonoid content (TFC) was expressed as $\mathrm{mg}$ of quercetin equivalent (QE) [23]. TFC was computed by using the following formula:

$$
\mathrm{TFC}=(R \times D . F \times V \times 100) / \mathrm{W} .
$$

where, R - result obtained from the standard curve, D.F - dilution factor, V - volume of stock solution, 100 - For 100 $\mathrm{g}$ dried plant, $\mathrm{W}$ - weight of plants used in the experiment.

\section{Percentage yield of extracts}

\section{Results and Discussion}

The percentage yield for the various solvent extracts of tepal of Musa paradisiaca is shown in Table 1. Ethanolic tepal extract (ETE) has the highest percentage yield when compared to the methanolic and aqueous extract of the flower.

Table 1. Percentage yield of various solvent extracts of tepal of Musa paradisiaca

\begin{tabular}{lccc}
\hline Extract & Initial weight & Final weight & \% Yeild \\
\hline Tepal (methanol) & 508.9 & 7.53 & 1.50 \\
Tepal (ethanol) & 508.9 & 7.54 & 1.51 \\
Tepal (aqueous) & 508.9 & 7.13 & 1.40 \\
\hline
\end{tabular}

\section{Preliminary phytochemical screening}

Preliminary phytochemical screening shows the presence of phenols, glycosides, flavonoids, alkaloids, tannins and terpenoids in all three extracts i.e. methanol, ethanol and aqueous. MTE has the highest contents of phenols, followed by the ETE and aqueous tepal extract (ATE) the least. Nonetheless, the aqueous extract possesses flavonoids in abundance. Glycosides, alkaloids, tannins and terpenoids were all found to be present. All extracts were tested negative for saponins.

\section{Total phenolic content (TPC)}

The TPC of the extracts was determined by extrapolation from the calibration curve $\left(Y=0.18 \mathrm{x}+0.1039 ; \mathrm{R}^{2}=\right.$ 0.994) prepared from the gallic acid concentrations (Figure 1) and expressed in mg of gallic acid equivalence (GAE) per gram. The amount of phenolic compounds in the various extracts was obtained from regression equation and the values were expressed in gallic acid equivalence (Figure 2). There was no significant difference $(p>0.05)$ in all the three different extracts. 


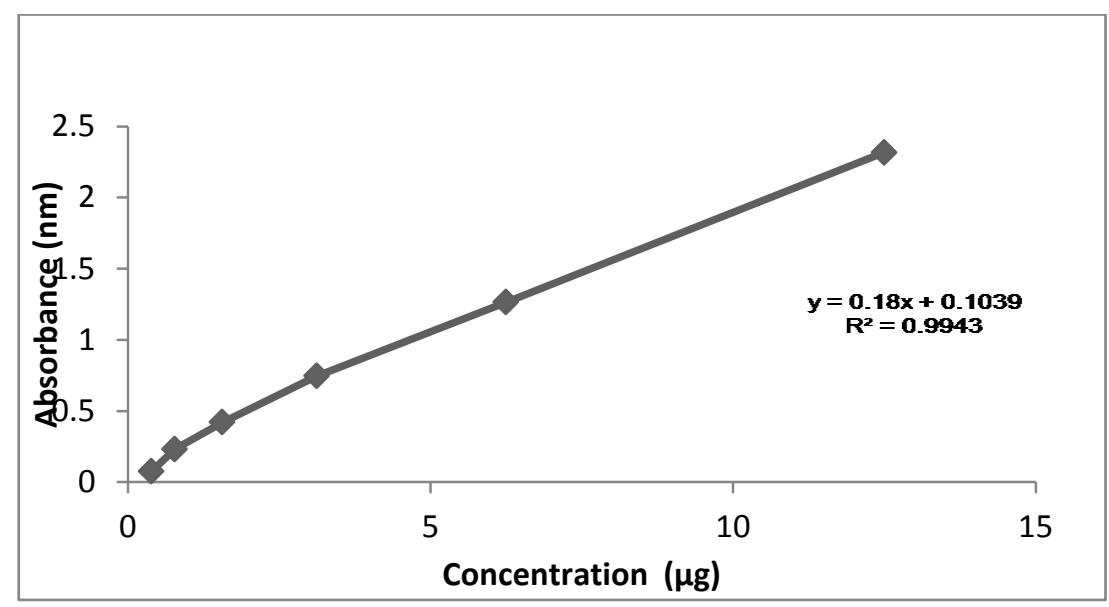

Figure 1. Gallic acid calibration curve

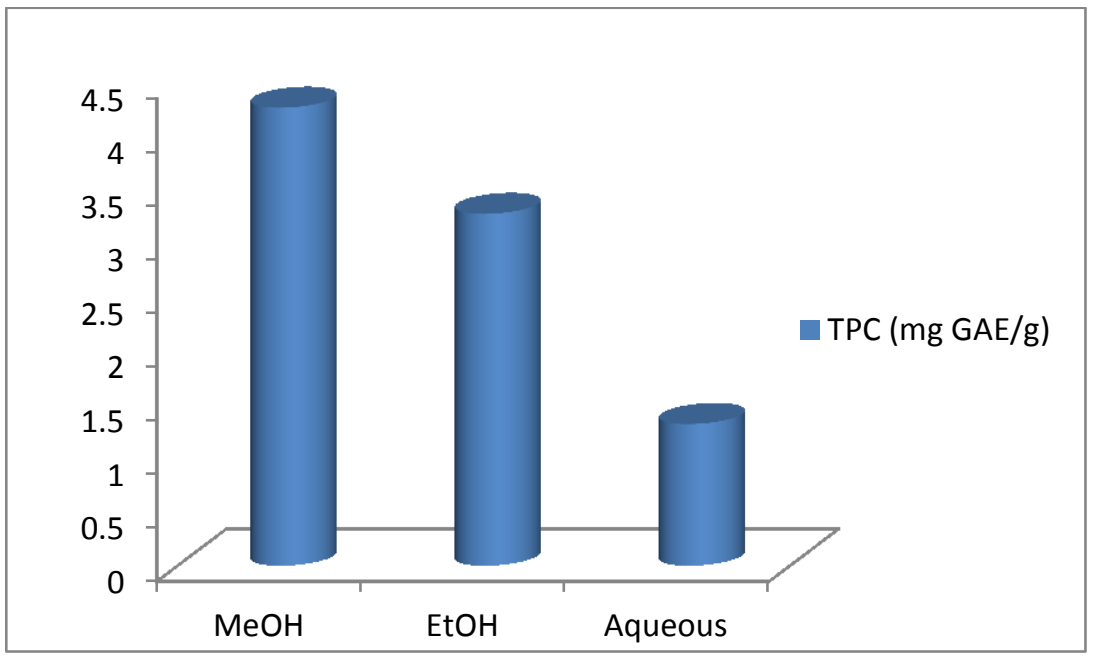

Figure 2. Total phenolic content of various solvent extracts of tepal of M. paradisiaca

\section{Total flavonoid content (TFC)}

The TFC content of the tepal extracts was also determined by extrapolation from the calibration curve $(\mathrm{Y}=0.4638 \mathrm{x}$ $+0.0778 ; \mathrm{R}^{2}=0.992$ ) prepared from the quercetin concentrations (Figure 3 ) and expressed in $\mathrm{mg}$ of quercetin equivalence $(\mathrm{QE})$ per gram. The amounts of flavanoid compounds in the various extracts were obtained from regression equation and the values were expressed in quercetin equivalence (figure 4). The values from all the extracts were not significantly different $(p>0.05)$. 


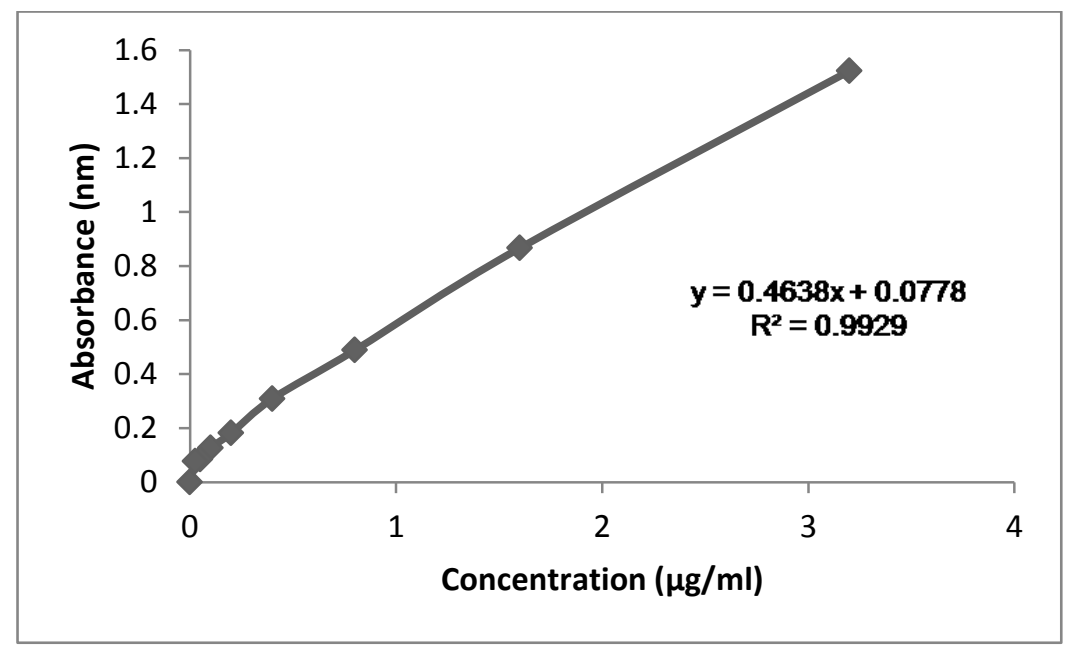

Figure 3. Quercetin calibration curve.

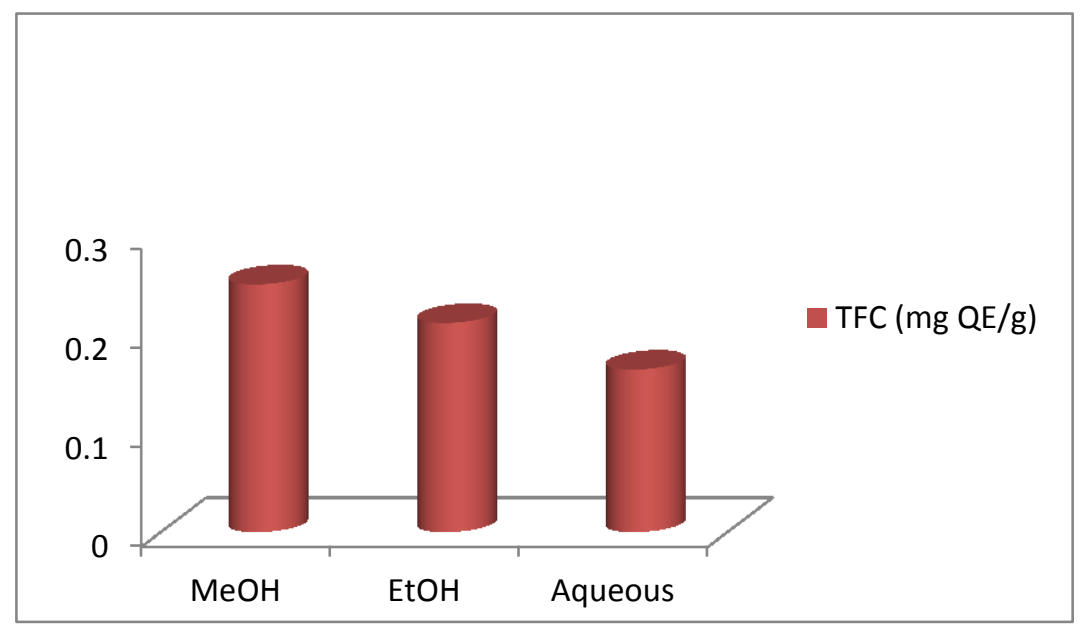

Figure 4. Total flavonoid content of various solvent extracts of tepal of M. paradisiaca

Preliminary phytochemical screening reveals the presence of phenols, flavonoids, glycosides, alkaloids, tannins and terpenoids. Saponins were tested negative in all the three different extracts (Table 2). The total phenolic content (TPC) of the tepal (methanolic, ethanolic and aqueous) extracts of Musa paradisiaca was determined using the Folin-Ciocalteau method. This method allows the estimation of all the flavonoids, anthocyanins and non-flavonoid phenolic compounds of all the phenolics available in the samples [24]. The results for total phenolic content in the studied plant extracts are presented in the graphs (Figure 2). The results show that MTE has the richest source of phenolics, total phenolic content is $4.272 \mathrm{mg} \mathrm{GAE} / \mathrm{g}$ while on the contrary, ATE possesses the lowest amount of phenolics i.e. $1.32 \mathrm{mg} \mathrm{GAE} / \mathrm{g}$. The total phenolic contents did not vary significantly $(\mathrm{p}>0.05)$ in different solvent extracts. This is in agreement with the researchers $[25,26]$, who found that yield of total phenolic was dependent on the method and choice of solvent. The recovery of polyphenols from plant materials is influenced by the solubility of the phenolic compounds in the solvent used in the extraction process. Furthermore, solvent polarity will play a key role in increasing phenolic solubility [27]. Thus, it is difficult to produce a standard extraction procedure suitable for phenol extraction of all the plant samples. As the results indicated, it is apparent that the recovery of 
phenolic compounds was dependent on the solvents used and their polarity. This may be attributed to the fact that wide range of phenols can dissolve in aqueous methanol mixtures. On the other hand, methanol is a good solvent system for the extraction of polar antioxidants [28]. There is a strong link between phenolic content and free radical scavenging activity $[29,30]$. Phenolics possess a broad spectrum of biochemical activities such as antioxidant, antimutagenic, anti-carcinogenic and even the ability to modify the gene expression [31]. Polyphenols are the largest group of phytochemicals that account for most of the therapeutic activity in plants or plant products [32]. This plant is generally reported to contain substantial amounts of polyphenols with pharmacological properties which includes flavonoids and tannins [33]. The results obtained in the present study revealed that the level of phenolic compounds in these extracts was considerable and falls within the values of commonly consumed green vegetables. Hence consumption of these plants will enhance the health benefits by absorbing and neutralizing free radicals, quenching singlet oxygen, or decomposing peroxides [3].

Table 2. Preliminary phytochemical screening of various solvent extracts of Musa paradisiaca

\begin{tabular}{llccc}
\hline S.N. & Test & T (MeOH) & T (EtOH) & T (aqueous) \\
\hline 1 & Saponin & - & - & - \\
2 & Phenols & ++ & ++ & + \\
3 & Glycosides & ++ & ++ & + \\
4 & Flavonoids & + & + & ++ \\
5 & Alkaloids & + & + & + \\
6 & Tannins & ++ & + & + \\
7 & Terpenoids & + & + & + \\
\hline
\end{tabular}

plus $(+)$ indicates the presence and minus (-) signifies absence.

Total flavonoid content (TFC) of different extracts of tepals of Musa paradisiaca was determined by $\mathrm{AlCl}_{3}$ method. Determining the total flavonoids by using $\mathrm{AlCl}_{3}$ is based upon the formation of stable complex between $\mathrm{AlCl}_{3}$, keto and hydroxyl groups of flavones and flavonoids. The results for total flavonoid content in the studied plant extracts are presented in the graph (Figure 4). The results show that MTE has the richest source of flavonoids, i.e. total content is $0.25 \mathrm{mg} \mathrm{QE} / \mathrm{g}$ while on the contrary, ATE possess the lowest amount of flavonoid i.e. $0.164 \mathrm{mg} \mathrm{QE} / \mathrm{g}$. this is contrary to the findings of [34] where it was found that ethanolic extract has the highest flavonoid content. Flavonoids display a crucial role in scavenging the free radicals and these are the phyto constituents that should be focused on for investigation of many biological activities. Phytochemicals especially polyphenols constitute a major group of compounds that act as primary antioxidants [15].

More than 4000 polyphenols (flavonoids, monophenols and poly phenols) are found in vascular plants. Phenolic compounds such as quercetin, rutin, narigin, catechin, caffeic acid, gallic acid and chlorogenic acid are very important plant constituents [15]. Medicinal plants are known to produce diverse substances possessing antioxidant properties having ability to protect the human body against cellular oxidation. Anti-oxidation are vital substances which possess the ability to protect the body from damage caused by free radicals inducing oxidative stress [35]. Antioxidant compounds like phenolic acids, polyphenols and flavonoids scavenge free radicals such as peroxide, hydroperoxide of lipid hydroxyl and therefore halt the oxidative mechanism that leads to degenerative diseases [36]. Flavonoids are proactive polyphenolic compounds found in most plants and cannot be synthesized or produced by the humans [37]. It was found to be effective in controlling various biological activities and is anti-inflammatory, anti-angiotic, antimicrobial, antioxidant, reduced hypertension, and has anti-cholesterol properties [38, 39]. In recent times, research interest has been paid to polyphenols and flavonoids as a result of their antioxidant capacity which is principally based on the redox properties of their hydroxyl groups and the structural relationship between different functional groups in their structure which enable them to actively serve as free radical scavengers, reducing agents, singlet oxygen quenchers metal chelators, and hydrogen donors [40]. 


\section{Rao et al: PHYTOCHEMICAL SCREENING, TOTAL FLAVONOID AND PHENOLIC CONTENT ASSAYS \\ OF VARIOUS SOLVENT EXTRACTS OF TEPAL OF Musa paradisiaca}

\section{Conclusion}

It can be postulated that the contents of phenolic and flavonoid compounds of tepal of Musa paradisiaca contribute to the radical scavenging activity and can be regarded as promising plant species for natural sources of antioxidant with potential value for treatment of many life threatening diseases. The process of extraction and identification of active principles responsible for the free radical scavenging property of tepal extract of Musa paradisiaca through bioactivity guided fraction is under progress in order to understand the possible mechanism of action of tepal of Musa paradisiaca. Utilization of this tepal will be of advantage to mankind and increased in its consumption will help in prevention of chronic life style diseases.

\section{Acknowledgement}

The authors would like to acknowledge the support of Faculty of Medicine, Universiti Sultan Zainal Abidin (UniSZA), for providing the necessary fund on this research work.

\section{References}

1. Rao, U. S., Khamsah, S. M., Abdurrazaq, M., Bashir, A. A., Mohaslinda, M. and Rosmawati, M. A. (2014). Taxonomical, Phytochemical and Pharmacological Review of Musa sapientum var paradisiaca. Research Journal of Pharmacy and Technology, 7(11): $1356-1361$.

2. Newman, D. J., Cragg, G. M. and Snader, K. M. (2003). Natural products as sources of new drugs over the period 1981-2002. Journal of Natural Product. 66 (7): 1022 - 1037.

3. Loganayaki, N., Rajendrakumaran, D. and Manian, S. (2010). Antioxidant capacity and phenolic content of different solvent extracts from banana (Musa paradisiaca) and mustai (Rivea hypocrateriformis). Food and Science Biotechnology. 19(5): 1251 - 1258.

4. Yen, G. C., Duh, P. D. and Tsai, H. L. (2002). Antioxidant and pro-oxidant properties of ascorbic acid and gallic acid. Food Chemistry. 79: $307-313$.

5. Bolkent, S., Yanardag, R., Tabakoglu-Oguz, A. and Ozsoy-Sacan, O. (2000). Effects of chard (Beta vulgaris L. var. cicla) extract on pancreatic B cells in streptozotocin induced-diabetic rats: A morphological and biochemical study. Journal of Ethnopharmacology. 73: 251 - 259.

6. Subash-Babu, P., Ignacimuthu, S., Agastian, P. and Varghese, B. (2009). Partial regeneration of [beta]-cells in the islets of Langerhans by nymphayol a sterol isolated from Nymphaea stellate (Willd.) flowers. Bioorganic and Medicinal Chemistry. 17: $2864-2870$.

7. Harborne. J. B. The Flavonoids: (1988). Advances in research since 1980, Chapman and Hall Ltd, New York. 121.

8. Nakamura, Y., Ishimitsu, S. and Tonogai, Y. (2000). Effects of quercetin and rutin on serum and hepatic lipid concentrations, fecal steroid excretion and serum antioxidant properties. Journal of Health Science, 46: 229 240.

9. Edeoga, H. O., Okwu, D. E. and Mbaebie, B. O. (2005). Phytochemical constituents of some Nigerian medicinal plants. African Journal of Biotechnology, 4(7): 685 - 688.

10. Singh, Y. N. (1986). Traditional medicine in Fiji: some herbal folk cures used by Fiji Indians. Journal of Ethnopharmacology. 15(1): $57-88$.

11. Leonard, D. B. (1998). Medicine at your feet: Healing plants of the Hawaiian Kingdom Musa spp.(Mai'a).

12. Mahmood, A., Ngah, N. and Omar, M. N. (2011). Phytochemicals constituent and antioxidant activities in Musa x Paradisiaca flower. European Journal of Scientific Research. 66(2): $311-318$.

13. Bagavan, A., Rahuman, A. A., Kaushik, N. K. and Sahal, D. (2010). In vitro antimalarial activity of medicinal plant extracts against Plasmodium falciparum. Parasitic Research, 108(2): $15-22$.

14. Sulaiman, C. and Indira, B. (2012). Total phenolics and total flavonoids in selected Indian medicinal plants. Indian Journal of Pharmaceutical Science, 74(3): 258 - 260.

15. Samatha, T., Shyamsundarachary, R., Srinivas, P. and Swamy, R. (2012) Quantification of total phenolic and total flavonoids contents in extracts of Oroxylum Indicum L. Kurz. Asian Journal of Pharmacy and Clinical Research, 5(4): $177-179$.

16. John, B. I., Sulaiman, C. T., George, S. A. and Reddy, V. R. (2013). Total phenolics and flavonoids in selected medicinal plants from Kerala. Intlernational Journal of Pharmacy and Pharmaceutical Science. 6(1): $406-408$. 
17. Peter, B., Kaufman, J., Warber, C., James, A. and Harry, D. (1999). Natural products from Plants, CRC Press London.

18. Dewick, P. M. (2001). Medicinal natural products. A biosynthetic approach, John Wiley \& Sons England.

19. Arnason, J., Mata, R. Romeo, J. (1995). Recent trends in Phytochemistry, (Eds) Plenum Press, New York and London.

20. Harbone, J. B. (1986). Phytochemical methods. Guide to modern techniques of plant analysis ( $2^{\text {nd }}$ edition. Chapman and Hall) India 1991.

21. Trease, G. E. \& Evans, W. C. (1989). Trease and Evan's Textbook of Pharmacognosy. $13^{\text {th }}$ Edition. Cambridge University Press, London. 546.

22. Singleton, V. L. and Rossi Jr J. A. (1965). Colorimetry of total phenolics with phosphomolybdic phosphotungstic acid reagents. American Journal of Enology and Viticulture. 16: $144-158$.

23. Kiranmai, M., Kumar, M. and Mohammed, I. (2011). Comparison of total flavanoid content of Azadirachta indica root bark extracts prepared by different methods of extraction. Research Journal of Pharmaceutical Biological and Chemical Science, 2: $254-261$.

24. Benvenuti, S., Pellati, F., Melegar, M. and Bertelli, D. (2004). Polyphenols, anthocyanins, ascorbic acid and radical scavenging activity of Rubus, Ribes and Aronia. Journal of Food Science. 69: 164 - 169.

25. Goli, A. H., Barzegar, M. and Sahari, M. A. (2005). Antioxidant activity and total phenolic compounds of pistachio (Pistachia vera) hull extracts. Food Chemistry. 92: $521-525$.

26. Atmani, D., Chaher, N., Berboucha, M., Ayouni, K., Lounis, H., Boudaoud, H. and Debbache, N. (2009). Antioxidant capacity and phenol content of selected Algerian medicinal plants. Food Chemistry, 112: 303 309.

27. Naczk, M. and Shahidi F. (2006). Phenolics in cereals, fruits, and vegetables: Occurrence, extraction, and analysis. Journal of Pharmaceutical and Biomedical Analysis, 41: 1523 - 1542.

28. Luximon-Ramma, A., Bahorun, T. and Crozier, A. (2003). Antioxidant actions and phenolic and vitamin C contents of common Mauritian exotic fruits. Journal of the Science of Food and Agriculture. 83: 496 - 502.

29. Oki, T., Masuda, M., Furuta, S., Nishibia, Y., Terahara, N. and Suda, I. (2002). Involvement of anthocyaninsand other phenolic compounds in radical-scavenging activity of purple-fleshed sweet potato cultivars. Food and Chemical Toxicology, 67: 1752 - 1756.

30. Mohammad Reza, S. A., Mahnaz, K., Mannan, H., Maryam J. and Abbas H. (2010). Comparison of antioxidant activity and total phenol contents of some date seed varieties from Iran. Iranian Journal of Pharmaceutical Research, 9(2): 141 - 146.

31. Marinova, D., Ribarova F. and Atanassova M. (2005). Total phenolics and total flavonoids in Bulgarian fruits and vegetables. Journal of Chemical Technology and Biotechnology, 40(3): $255-260$.

32. Sulaiman, C. T., Sadashiva, C. T., George, S., Goplakrishnan, V. K. and Balachandran, I. (2013). Chromatographic studies and in vitro screening for acetyl cholinesterase inhibition and antioxidant activity of three Acacia species from South India. Analytical Chemistry Letters, 3(2). 111 - 118.

33. Lewis, D. L., Field, W. D. and Shaw, G. P. (1999). A natural flavonoid present in unripe plantain banana pulp (Musa sapientum L. var. paradisiaca) protects the gastric mucosa from aspirin-induced erosions. Journal of Ethnopharmacology. 65: $283-288$.

34. Joseph, J., Paul, D., Kavitha, M. P., Dineshkumar, B., Menon, J. S., Bhat, A. R. and Krishnakumar, K. (2014). Preliminary phytochemical screening and in vitro antioxidant activity of Banana flower (Musa paradisiaca AAB Nendran variety). Journal of Pharmacy Research. 8(2): 144 - 151.

35. Ozsoy, N., Can, A., Yanardag, R. and Akev, N. (2008). Antioxidant activity of Smilax excelsa leaf extracts. Food Chemistry, 110: 571 - 583.

36. Subramanian, H., Gupta K., Guo, Q., Price, R. and Ali, H. (2011). Mas-related gene X2 (MrgX2) is a novel G protein-coupled receptor for the antimicrobial peptide LL-37 in human mast cells: resistance to receptor phosphorylation, desensitization, and internalization. Journal of Biological Chemistry. 286: 44739 - 44749.

37. McCullough, M. L., Peterson, J. J. and Patel, R. (2012). Flavonoid intake and cardiovascular disease mortality in a prospective cohort of US adults 1-4. American Journal of Clinical Nutrition. 95(2): $454-464$.

38. Knekt P., Kumpulainen J., and Jarvinen J. (2002). Flavonoid intake and risk of chronic diseases. American Journal of Clinical Nutrition, 76(3): 560 - 568. 


\section{Rao et al: PHYTOCHEMICAL SCREENING, TOTAL FLAVONOID AND PHENOLIC CONTENT ASSAYS}

OF VARIOUS SOLVENT EXTRACTS OF TEPAL OF Musa paradisiaca

39. Liu X, Zhu L, Tan J., Zhou, X., Xiao, L., Yang, X. and Wang, B. (2014). Glucosidase inhibitory activity and antioxidant activity of flavonoid compound and triterpenoid compound from Agrimonia Pilosa Ledeb. BMC Complement Alternative Medicine. 14(1): 1 - 12.

40. Materska M. and Perucka I. (2005). Antioxidant activity of the main phenolic compounds isolated from hot pepper fruits (Capsicum annuum L.). Journal of Agricultural Food Chemistry. 53:1730 - 1758. 